\title{
An African Dilemma: Pastoralists, Conservationists and Tourists - Reconciling Conflicting Issues in Kenya
}

\section{Damiannah Kieti', Rita Nthiga ${ }^{2}$, Jonathan Plimo³, Pratima Sambajee ${ }^{4}$, Ann Ndiuini ${ }^{5}$, Ezekiel Kiage $^{6}$, Peter Mutinda ${ }^{7}$ and Tom Baum ${ }^{8}$}

\begin{abstract}
Kenya is facing irreconcilable tensions by competing interests from conservationists, tourism developers and pastoralists. Concerns arising from the well-being of flora and, in particular, fauna by conservationists; tourists and commercial tourism; and the increasingly restricted use of traditional lands and herding animals by pastoralist indigenous communities, have populated the discourse of land use in Kenya. In this paper, we look into the varying perceptions of each group of stakeholders and seek to analyse the current narrative that gives priority to wildlife protection and the commercial exploitation of wildlife through high-end tourism development to the detriment of the rights and interests of pastoralism. As pastoral land becomes more appropriated, our analysis shows that the antagonistic relationship between conservationism, commercial tourism and pastoralism is likely to deteriorate. We therefore propose a more participatory model of tourism development that will allow pastoralist communities to have a voice in the process.
\end{abstract}

Keywords: Pastoralism, Conservationism, Tourism Development, Land use and rights, Kenya

\section{Introduction}

\footnotetext{
${ }^{1}$ Moi University, Eldoret, Kenya

${ }^{2}$ Moi University, Eldoret, Kenya

${ }^{3}$ Moi University, Eldoret, Kenya

${ }^{4}$ University of Strathclyde, Scotland

${ }^{5}$ University of Strathclyde, Scotland and Oxford Brookes University, England

${ }^{6}$ Moi University, Eldoret, Kenya

${ }^{7}$ Moi University, Eldoret, Kenya

${ }^{8}$ University of Strathclyde, Scotland and University of Johannesburg, South Africa (corresponding author)
} 
Kenya is facing irreconcilable tensions by competing interests from conservationists, tourism developers and pastoralists. In this paper, we look into the varying perceptions of each group of stakeholders and seek to analyse the current narrative that gives priority to wildlife protection and the commercial exploitation of wildlife through high-end tourism development to the detriment of the rights and interests of pastoralism.

Tourism is one of the largest and fastest growing economic sectors globally significantly contributing to the economies of different countries and communities. (UNWTO, 2019). The growth is expected to increase by an average of 3.3\% per annum, reaching 1.8 billion by the year 2030. The sector holds the future of many economies globally having contributed $5 \%$ of gross domestic product (GDP), 30\% of service exports and 235 million jobs in 2017 (Signe', 2018).

According to United Nations World Tourism Organization (UNWTO, 2016, 2017, 2018, 2019), key highlights on Tourism growth across continents, Africa has experienced continued growth over the years. The number of international arrivals to Africa increased from 57 million in 2016 (UNWTO, 2017) and 63 million in 2017 (UNWTO, 2018) to 67 million tourists in the year 2018 (UNWTO, 2019). The contribution of the tourism industry to the GDP and exports of many African countries has been growing over time. A report by Knoema (2019) indicates that tourism in Kenya, South Africa, Uganda and Nigeria, contributed 8.8\%, 8.6\%, 7.7\% and 5\% to respective country's GDP. Moreover, between the years 2011-2014, the tourism sector in Africa generated approximately 1 out of 14 jobs, thereby creating more than 21 million jobs (UNWTO, 2018).

\section{Tourism in Kenya}

Kenya is heavily dependent on tourism as a source of revenue for central government and a variety of other county government authorities. Consequently, the tourism industry has continued to feature prominently in policies, plans and programmes for Kenya's economic growth. The tourism sector in Kenya played a significant role towards realization of the goals set out in the Economic Recovery Strategy for Wealth and Employment Creation-ERSWEC (2003-2007) (Kenya government, 2004). After the successful implementation of ERSWC, which enabled the country's economy back on track for rapid growth since 2002, when GDP grew from a low of 
$0.6 \%$ and rising gradually to $6.3 \%$ in the first quarter of 2007 (Ministry of Tourism, 2010), the government launched Kenya Vision 2030. The Vision is anchored on pillars significant and relevant to tourism. One pillar is envisaged on achieving a sustainable economic growth of over $10 \%$ per annum, whereas the other seeks to build a just and cohesive society with equitable social development (Kenya Government, 2007). Tourism has been listed as the leading player amongst the six priority sectors identified by the Kenyan government to raise the national GDP growth rate to $10 \%$ per annum (Ministry of Tourism, 2010). Since independence, Kenya has continued to significantly rely on two forms of tourism; coastal and safari tourism (Akama, 2013). The latter constitute places of abundant wildlife resources (Ministry of Tourism \& Wildlife, 2018a) Thus, wildlife stands at the centre of Kenya's tourism offering and as a result, renders communities that live close by these wildlife resources an important tourism stakeholder.

Reflecting on tourism development in developing countries, Akama (2000) and Sindiga (1999) point out that the prime motivation for developing tourism is as a contributor to economic growth and much- needed foreign exchange earnings. This drives the the assumption that as tourism develops economic benefits are spread out to communities, particularly those nearby. (Kieti et al., 2009). Often economic tourism development models are not accompanied by the creation of local linkages to allow for equitable distribution of socio-economic benefits to the lowest echelons of society (Kamsma \& Bras, 2000). Evidence suggests that majority of tourism development initiatives in Kenya under private businesses and public agencies fall under this model of tourism development (Kieti, 2007). Economic objectives remain the top priority, overshadowing community societal and environmental objectives (Elliott \& Mann, 2005; Ioannides, 2003). Consequently, a majority of local people do not capture much of the income generated from tourism and consider themselves impoverished.

\section{Land use and land rights}

In all nations of the world, land continues to play a crucial role, both as an important resource for the economic life of people as well as a source of political power. For many, it is a major asset 
(Azadi \& Vanhaute, 2019) given its critical production factor to sustain livelihoods and as a means to food security (Quan et al. 2004). Moreover, the way people perceive and use land is a reflection of their social and economic status, livelihood strategies, well-being, as well as, the quality of land resources (FAO. n.d; Kenya Land Alliance-KLA, 2016). There are many uses of land in Kenya: for agriculture, pastoralism, water catchments, nature reserves, urban and rural settlements, industry, mining, transport and communications, tourism, recreation (Kenya Government, 2017a). Primarily, the Kenyan economy is agro-based and approximately $90 \%$ of the population living in rural areas derives their livelihood directly from land related activities (KLA, 2016). The World Bank, (2003) acknowledge that in a majority of rural populations, land is a significant means for generating a livelihood and investing, accumulating wealth, and transferring it between generations. This is because land resources determine people's ability to fulfill their social-cultural, political and economic obligations (KLA, 2016).

Ogutu et al. (2016) estimates that close to $10-12 \%$ of Kenya is designated for biodiversity conservation, with wildlife protected areas covering $8 \%$ and the rest consisting of forests, water catchments and private sanctuaries. The percentage of terrestrial areas in Kenya covered by protected and strict protected areas is $11.4 \%$. However, over the years, $6.8 \%$ of protected areas in East Africa have been converted to agriculture and/or human settlement (Riggio et al., 2019). In Kenyan Maasai landscape, primarily pastoralists and wildlife areas, agriculture has engulfed $8 \%$ of the rangelands, with wheat farms occupying a significant portion of the previous wet season range of the migratory wildlife. In the Amboseli landscape, communal rangelands have been subdivided into small parcels of land, a transformation driven by the belief that subdivision and privatization of communal land would increase investments in ranching and agricultural production systems. This makes difficult for wildlife in Kenya's rangelands to access grazing and water and to move between key dry and wet season resources. Consequently, wildlife densities have been reported to decline within and around protected areas. Nelson (2012), reported a 56\% decline in resident wildlife population in the East Africa savannahs of Kenya and Tanzania. The loss of wildlife population is attributed to climate change, land 
use changes and habitat loss through land fragmentation and conversion to cultivation among other factors (Ogutu et al., 2017; Green et al., 2019).

Over the last three decades, there have been significant changes in land uses in Kenya. Cultural practices, population growth, urbanization and growth of towns have led to subdivision and conversion of land into residential, commercial and other uses (Kenya Government, 2017a). Large farms have been subdivided and transferred from state to private ownership, and many smallholder areas are continuously getting fragmented into much smaller and uneconomic sizes, which cannot support viable agricultural or livestock production (Ogutu et al., 2017; Pas Schrijver, 2019). The processes of subdivision are attributed to poor governance and past policy design (ELCI, 2006; Bedelian, 2014; Byakagaba et al., 2018;). Despite the value pastoralists land uses offer to the rising wildlife tourism, Kenyan wildlife policies and laws continue to place restrictions on pastoralists land uses, particularly on the ability of communities to capture revenues from tourism (Homewood et al, 2012). Consequently, Byakagaba et al. (2018) note that the current trends of individualization of rangeland has augmented pastoralists exposure to risks by denying them benefits accrued from landscape heterogeneity in amalgamated landscape, such as access to common grazing land, water and dry season resources. The traditional solidarity, which existed amongst the pastoralists, is at the verge of disappearance, leaving behind profound social strains, something which current transformations and subdivision of communal land seems to propagate.

Generally, pastoralist communities emphatically link assets to access to basic needs; increase in security; strengthening of family ties and shared community action; increase in ones' control and confidence to make decisions and choices and enhancement of intra and inter-generational equity, through inheritance and asset sharing (Kieti, 2007). However, as the per capita availability of livestock and land continues to reduce due to increasing subdivision of communal land and constrained mobility of livestock, more pastoralists are likely to experience severe economic hardship. As individualization and communal land sub division cause social fragmentation, which Kaye-Zwiebel \& King (2014) caution that reduce social cohesion and collective action within a community, yet are assets that are crucial for enduring and 
adjusting to changing environmental conditions. Moreover, social cohesion and social ties are the only source of social insurance available to the most vulnerable, and "includes" rather than "excludes" less most vulnerable groups (Narayan et al., 2000:175). Hence a breakdown of community cohesion and solidarity is deemed to increase material, psychological and social strains of destitution (Kieti et al., 2009).

Ogutu et al. (2016) established that on average, Kenya's wildlife population in rangelands declined by 68\% between 1977 and 2016. Similarly, Green et al. (2019) study in Mara- Serengeti ecosystem revealed a decline in both resident and migrant herbivores abundance, species richness and evenness between 1988 and 2013.

\section{The rights and interests of pastoralism}

Pastoralism in East Africa and particularly in Kenya goes back some 5,000 years and has long adapted to the risk of living in tropical rangelands (Hesse \& MacGregor 2006). In modern Kenya, pastoralism is considered in the context of subsistence pastoralism, not market pastoralism; i.e. pastoralism with a survival orientation, not profit-driven (Atsedu et al., 1996). According to Odote (2013), pastoralism is an important and expansive land use in Kenya's ASALs. Kenya's pastoral areas are also known as rangelands and are characterized by aridity, rough terrain, low investment and policy neglect by government (Odote, 2013). The extant policy environments are often harmful to pastoralism (Notenbaert et al., 2012), and the land policies are neither consistent with needs nor responsive to the uniqueness of the pastoral system (Humanitarian policy group, 2009).

Other challenges facing pastoralist societies include problems of pastoral governance and development including the "tragedy of the commons" debate, which threatens common property rights of pastoral communities (Bedelian, 2014). According to Odote (2013), policy and law under the legal framework that has existed since Kenya's independence in 1963, local communities have been viewed as unfavorable to the sustainable management of natural resources therefore, preference for private ownership and vesting rights of certain important 
resources such as wildlife to the national government. Historical injustices experienced by a majority of pastoralist communities, particularly the Maasais, are still fresh in their minds and have been passed on to subsequent generations (Okello \& Wishitemi, 2013). In the past national, regional and international policy process, the pastoralists societies have been excluded (Humanitarian Policy Group, 2009), giving way to bias land use for intensive crop and livestock development.

In Kenya, loss of pastoral lands to biodiversity conservation, and alternative land uses through privatization of rangelands are the most commonly reported manifestations of land grabbing (Galaty, 2013). Moreover, according to the Segovia Declaration, in many societies, governments have 'nationalised' and confiscated rangelands, forests and other natural resources on which pastoralists depend alienating nomadic pastoralists from their natural rights'(Segovia Declaration, 2007). Rights-based discourses on land are also evident in diverse documentation of the activities from the World Alliance of Mobile Indigenous Peoples (WAMIP), World Initiative for Sustainable Pastoralism (WISP) and the Dana Declaration (WAMIP, 2004; WISP, 2013). Distributive injustice is also invoked in reference to pastoralists' often limited access to education and healthcare (Segovia Declaration, 2007). This is in addition to loss of land to conservation related displacements and land grabbing (Chatty, 2012). However, with immense potential for socio-economic development through poverty reduction, economic growth, managing the environment, promoting sustainable development, and building climate resilience pastoralism as a land use has been embraced for ages and continues to be embraced even in the wake of increasing drought prevalence and population explosion in the otherwise considered expansive vast areas (United Nations, 2008). According to Chatty (2003), there are conflicts, tensions and possible synergies between mainstream conservation practice and 'mobile peoples'. Moreover, Upton (2014) argues that over time, indigenous people who were especially prone to conservation-related environmental injustices in terms of constraints on resource access, and were lacking a voice in global arenas, their voice has been fronted. This is through initiatives such as World Initiative of Sustainable Pastoralism (WISP), the Dana Declaration on mobile peoples and conservation, International Union for Conservation of Nature (IUCN) World Parks Congress and the World Conservation Congress (WCC). 


\section{Pastoralism and the political ecology of conservation}

Political ecology is an interdisciplinary approach to the analysis of natural resources access, control and management that accentuates the interaction between multiple actors at varying extents over time (Bassett \& Gautier, 2014). Political ecologists analyse environmental/natural conditions as the creation of political, economic and social processes that help shape humanenvironmental relations (Masse, 2016;) and argue that the way nature is understood has intense political implications (Adams \& Hutton, 2007). The creation of protected areas, for example, is done by different social and political actors, grieved by other actors and enjoyed by yet another set of actors (Vaccaro et al., 2013). These distinct actors define nature, legitimacy, rights or use in very diverse and culturally dependent ways (Vaccaro et al., 2013). The significance of conservation and related dislocation of indigenous people has been to create wilderness or nature spaces separate from communities, livestock and related livelihood activities (Masse, 2016; Pas Schrijver, 2019), thereby estranging the very people from nature who depend on it and without whose backing, conservation will not be fully realized (Adams \& Hutton, 2007; Vaccaro et al., 2013; Masse, 2016). These developments are a manifestation of political processes that have far reaching implication for the livelihood of pastoralists especially in relation to accessing and controlling resources (Masse, 2016; Pas Schrijver, 2019).

In Kenya, the Laikipia ecosystem is a classic example of pastoralism- wildlife conservation conflict as a result of exclusionary practices, where armed pastoralist communities invaded private ranches which are home to wildlife conservation areas, moved their livestock herds forcefully to the private ranches, destroyed property, displaced and caused death of wildlife species. Elsewhere in Maasai Mara ecosystem, conflicts pitting pastoralists and Maasai Mara National Reserve authorities have been on the rise. Yurco (2017) locates the persistent humanwildlife conflicts experiences in Laikipia and Maasai Mara at the centre of political-economic dynamics, where resources inequalities and contesting desires for land use have resulted in a complex group of wildlife-tolerant and wildlife-intolerant factions of stakeholders. Yurco (2017)

further notes that at the very best pastoralists have had less economic or political capacity to put 
up with wildlife related challenges and at worst, they have been weakened by more powerful stakeholders. The situation is often aggravated by political consternations such as corruption, which make it almost impossible for the poor and vulnerable to play any meaningful role in tourism and wildlife conservation, thereby jeopardizing their rights (Kieti et al, 2009).

However, there has been a growing appreciation of wildlife conservation as a social and political process with special emphasis on the need to incorporate local communities in sustainable use of natural resources. Like Vaccaro et al. (2013) noted conservation, NGOs including World Wildlife Fund for Nature (WWF) among others have redefined the concepts of nature, use and jurisdiction in order to reflect nature and culture in their work. As a result, conservation-based agreements have been devised to integrate pre-modern forms of natural resources management and local communities in conservation activities. With respect to pastoral communities, donors and other global players have recognized the potential of the pastoral communities in conservation of natural resources. For example, pastoralists have been referred to as the 'custodians of the commons' (Upton, 2014). The recognition of the contribution of pastoral communities to conservation is evidenced in the Community Based Natural Resources Management (CBNRM) conservation paradigm (Burrow \& Muphree, 2001). CBNRM treats conservation as instrumental to community development and vice versa. CBNRM further seeks to give natural resources a meaningful use-value to rural communities who bear the cost of wildlife and habitat conservation (; Hackel, 1999;). The challenges, however, relate to CBNRM's inclusion of stakeholders especially communities in the decision-making process, domination by political elites, white land-owners and safari operators (Metcalf, 1994; Bourne \& Blench, 1999). In other words, CBNRM is a programme essentially propelled by initiatives which are exogenous to local communities thereby fostering the agenda of external factors (Musavengane \& Simatele, 2016). An additional challenge is insufficient compensation to communities evicted from conservation areas (; Kideghesho, 1999). There is also the challenge of financial dependence on bilateral donors, Non-Governmental Organizations and corporations, considerably restricting the degree to which a community can make managerial decisions (Bourn \& Blench, 1999). Reflecting on the CBNRM programme, Musavengane \& Simatele (2016) asserts the need for CBNRM programmes to embrace co-management principles and 
participation of all community stakeholders, with special focus on creating opportunities for local communities to take the lead.

It is suggested that small conservation related enterprises are appropriate alternative livelihood strategies because they are: a) less disruptive, b) associated with higher multiplier and smaller leakages, c) have control in local hands, and d) are more likely to generate greater local benefits (Wall \& Long, 1996; Adiyia et al., 2017). However, pastoralists communities' experiences suggest the opposite may be the case. For instance, it is estimated that $96 \%$ of the revenue accrued to the cultural maasai manyattas (indigenous tourism enterprises) remain at the hands of tour drivers (Homewood et al., 2012; Bedelian, 2014). While the entry fee for each tourist to a Maasai cultural manyatta in Maasai Mara is approximately US\$30, the sharing ratio is USD 10 for the tour-company, USD 10 for the tour driver, and USD 10 for the cultural village. Elsewhere, Tumusiime's \& Vedeld's (2012) study revealed that most of the revenue from Uganda's Bwindi Impenetrable National Park is remitted directly to the UWA's central treasury and only USD 5 out of USD 500 paid by tourists is shared by the community. Evidently, tourism revenues are unevenly distributed with the well placed individuals seizing most revenue (Bedelian \& Ogutu, 2017). This is an exploitation of resources where benefits of cultural consumption by visitors are channeled to the powerful stakeholders, including tour drives and little shared to the community members. This reduces the community's trust and support for conservation and wildlife-based tourism and creates 'winners and losers' scenario where the winners are the government, the wildlife and the private business community.

A study by Akama \& Kieti (2007) found that an overwhelming majority of international tourists to Kenya travel under inclusive tour packages. As it is usually the case, such forms of tourism packages are rather difficult for local entrepreneurs to access (Goodwin, 1998). Consequently, any visit to the cultural manyattas typically serve the interest of tour drivers whose choice of a cultural manyatta where the gatekeepers are likely to demand less of entry fees, is left at the drivers' discretion. This often proceeds on the pretext that 'if these operators did not come, there would be no money injected into the community at all' (Wearing \& McDonald, 2002:15). In his study in Turkey, Tosun (1998) found that tourists were frequently directed to visit pre- 
determined large shops with which tour guides and hotel companies own or have made a commission contract. It should be noted that the more unequal distribution of benefit there is, the larger the percentage of the population who are living in poverty. In essence, persistent inequitable distribution of tourism benefits in most of the pastoralist communities living adjacent to protected areas has translated into an increasing number of vulnerable groups, particularly women, youth and the elderly falling into poverty. Moreover, Timothy \& Tosun (2003) assert that when control lies in the hands of external forces, community cohesion and cooperative spirit diminish and consequently practices, such as unhealthy competition and individualism, tend to replace the traditional social set-up where profound emphasis is laid on group welfare. Meanwhile, Ennew (2003) argue that even if high levels of leakages may lead to low multipliers, if the level of expenditure is relatively high in total, the benefits may still be significantly greater than those which would arise from economies with low leakages but low levels of expenditure. This may be so, especially if tourists to cultural manyattas spent more on the purchase of, for instance, local handicrafts and other souvenirs. However a majority of communities experience difficulties in getting tourists to purchase their handicrafts and spend money there.

Whilst a majority of the local communities living adjacent to protected areas acknowledge provision of education and meagre health services, their lives have remained largely unchanged (Kieti, 2007), they are still unable to escape from poverty traps (Homewood et al., 2012). Consequently, they continue to suffer from social-economic poverty strains, including physical pain that comes with lack of enough food, emotional pain stemming from daily humiliation, desperation and one not being able to clothe his/her family (Kieti, 2007). Given their lifestyle and priorities, some members from pastoral communities like the Maasai's, maybe less concerned about, for instance, attending school, instead the focus may be on the possible sources of their next meal. However, it is worth noting that a majority of community development initiatives adjacent to protected areas are usually meant to prevent the affected communities from taking direct action themselves, which would involve hunting down and killing wild animal species involved (Obunde et al., 2005). 


\section{Pastoralist-Tourism Compatibility}

Conservation and development partners including Environmental Liaison Centre International (ELCI) have rooted for tourism development, particularly, wildlife-based tourism, as the most viable alternative livelihood that is compatible to pastoralism (ELCI, 2006). Proponents of this diversification strategy observe that pastoralist communities have rich cultural values, heritage, artifacts and natural resources that can support sustainable community- based tourism (Jenet et al., 2016). This philosophy has therefore led to the introduction of different forms of tourism in pastoralist areas. Most pastoralist communities than any other community have accommodated wildlife. The compatibility of wildlife conservation and pastoralist has been tested in different geographical areas and communities within the continent. The evidence that exists reveal that pastoralists have long co-existed with wildlife (Yurko, 2017) and that it is the pastoralists way of life that has made it possible for wildlife to continue to flourish in the rangelands (ELCI, 2006; Nelson, 2012). For example, in his study on the impact of pastoralist land use practices on Tanzania's wildlife economy, Nelson (2012) reported that the herbivory effect of cattle was comparable to that of Zebras; where they stimulate renewed growth that gazelles and other small mammals can eat. However, pursuing wildlife-based tourism and pastoralism has, in recent times, come into collision especially when carnivorous wildlife hunt domestic animals, and/or wildlife spread diseases to livestock, and more importantly, conflict emerges when pastoralists are denied access to grazing areas once declared a wildlife protected area (conservancies, reserves and parks). This is one of the unending conflicts between the local pastoralist communities and wildlife authorities with local communities who have co-existed with wildlife for many years, yet until recently being declared a threat to the existence of the same wildlife. One of the disquieting scenarios is the pervasive invasion by wildlife, which has plunged the majority of pastoralists into the poverty trap. Studies by Wishitemi \& Okello (2003) reveal that over $60 \%$ of the local communities in Amboseli ecosystem lose their crops and livestock annually as a result of wildlife invasion. Elsewhere in Laikipia ecosystem, Obunde et al. (2005), found that the majority of residents face food shortage because of frequently invasion by wildlife. Consequently, residents adjacent to protected areas have continued to suffer from chronic poverty, which forces them to rely on external sources of support, such as, remittances and relief food in order to cater for their household needs (Kieti 2007). 
Although literature has highlighted instances where tourism has come into conflict with other forms of land use (Kristjanson et al., 2002), there are a number of destinations where pastoralism and tourism have co-existed well and resulted in mutual benefits for both land uses and benefited the local communities. For example, the Il Ngwesi Maasai in Laikipia ecosystem set aside approximately $60 \%$ of their land for tourism and wildlife conservation (group ranch), which they use to graze cattle only in drought periods (Kieti, 2007). The remainder of the land (40\%) is used by members to live, cultivate, and graze cattle. A Group Ranch Committee and Chairman manage the ranch on behalf of the 6,000 members. The committee oversees the running of the group ranch activities in line with the Cap 276 of the laws of Kenya. Tourists' activities in the ranch include; wildlife viewing, night game drives, bush walks, camel rides and visit to cultural centres. The community own Il Ngwesi Eco-Lodge, which has six spacious sleeping grass thatched huts, commonly known as 'bandas'. Usually a conservation fee of US\$20 per noresident and US\$10 per resident per night is payable by all guests who visit the ranch.

Of the different forms of tourism, wildlife- based tourism emerges as the one that enjoys the strongest compatibility with pastoralism, where pastoralist areas apart from providing forage for livestock also provide excellent habitat for wild animals which support tourism developments. Significant wildlife numbers continue to exist in pastoralist inhabited areas and more conservancies continue to be established in these areas (Nelson, 2012; Kenya Wildlife Conservancies Association, 2016). Even though conservancies limit access to and use of pastoral grazing land, they maintain rangeland open by amalgamating individual parcels of land and having them free of fencing, cultivation and other land-use changes, thereby being in harmony with mobile livestock keeping (Bedelian \& Ogutu, 2017). More importantly, the environmental services provided by pastoralism contribute not only to ecosystem function, but to the amenity value of the rangelands, which in many countries is instrumental for generating significant income from tourism (WISP, 2008).

Although much of the existing literature paints a positive picture of pastoralist-tourism compatibility, recent happenings have shown that pastoralism and tourism development have 
come into collision. Recorded pastoralist-tourism related conflicts revolve around fights over water sources, grazing land, denial of access routes, fines on trespass animals among other conflicts (Kristjanson et al., 2002; IWGIA et al., 2016). While safari tourism has gained currency as one of Kenya's unique tourism products especially at international scale, there are negative under-currents which not only fail to get much needed attention but also may put the entire product under serious jeopardy. Most of the safari tourist activities take place in rangelands which are traditionally inhabited by pastoralist communities. A number of studies have underscored the intricate relationship between land and land use, and the local communities support for and participation in conservation efforts (Kristjanson et al., 2002; Mureithi et al., 2019). Hence, to link tourism to pastoralism, there must be an understanding of aspirations and priorities of the pastoral communities, whether general to the community or specific to individuals. Communities must be considered as the main actor in the tourism development process hence, actively participate in the implementation of strategies and the operation of the tourism infrastructure, services and facilities. This implies that tourism development models need to be (re) designed in such a way that the pastoralist communities are able to exercise their rights in steering up development of spaces they own and inhabit and have a greater say in the process. Moreover, tourism development should be seen to strengthen community cohesion within the pastoralist communities to enable them to have a meaningful interaction with the outside community and to negotiate more effectively on issues that affect their well-being. Increased community cohesion would translate to increased bargaining power and social insurance for the vulnerable Maasai communities and other pastoralist communities. Likewise, a conservation model that goes beyond protected area boundaries to safeguard vast landscapes of cultural, biological and historical significance should be embraced. Such a model should involve the local communities and tie together conservation ideals and the aspirations of indigenous local communities (Okello \& Wishitemi, 2013).

\section{Conclusion}

Pastoralists' culture and lifestyle has interacted with the physical and biological environment to produce a distinct landscape that has supported pastoralism lifestyle, as well as, conservation of 
biodiversity for many years. Indeed, the pastoral communities have over the years followed a pastoral livestock land use system, which is largely compatible with wildlife conservation. However, in the recent past, the pastoralist communities, including those living in Maasai land and Samburu have diversified their livelihood options into small scale and large scale cultivation. Such land use options have been seen to compete with both traditional pastoral livestock keeping and wildlife- base tourism. Moreover, the support for vibrant tourism activities and a healthy livestock economy is threatened by increasing human population, land subdivision, changing land tenure systems, crop farming, habitat fragmentation, blockage of migratory corridors, environmental degradation and poverty. Indeed, most of the pastoral community lands in Kenya are experiencing human-wildlife conflicts, which threaten the local communities' livelihoods and conservation. The very participation of pastoral communities in decision making processes regarding land and other resources that directly affect their livelihood should be appreciated as a fundamental human right.

\section{References}

Adams, WM, 2004. Against extinction: The story of conservation. Earthscan, UK.

Adams, WM \& Hutton J, 2007. People, Parks and Poverty: Political Ecology and Biodiversity Conservation. Conservat Soc 5:147-83. http://www.conservationandsociety.org/text.asp? 2007/5/2/147/49228. Accessed 7 February 2020.

Adiyia, B, De Rademaeker, S, Vanneste, D \& Ahebwa, WM, 2017. Understanding local entrepreneurship and small enterprises in the tourism-development nexus: The case of western Uganda. Development Southern Africa, 34 (1), 105-120. https://doi.org/10.1080/ 0376835X.2016.1259991. Accessed 2 February 2020.

Akama, JS, 2000. The Efficacy of Tourism as a Tool for Economic Development in Kenya. Development Policy Management in Sub-Saharan Africa. 7(1), 13-18.

Akama, JS, 2013. The evolution of wildlife conservation policies in Kenya. In Akama, J S (Ed), Tourism development in Kenya: Critical issues, challenges and alternatives in the new millennium.East African Educational Publishers Ltd., Nairobi. 
Akama, JS \& Kieti, DM, 2007. Tourism and Socio-economic Development in Developing Countries. A case Study of Mombasa Resort in Kenya. Journal of Sustainable Tourism 15 (6), $735-48$.

Ashley, C \& Garland, E, 1994. Promoting community-based tourism development: Why, what and how? Research Discussion Paper No. 4.October,Windhoek.

Atsedu, M, Coughenour, MB \& Swift, DM, 1996. Arid and Semi-arid Ecosystems. In McClanahan, TR \& Young, TP (Eds), East African ecosystems and their conservation. Oxford University Press, Oxford.

AWF, 2005. Samburu: The heartland of Kenya. http://www.AWF Samburu the Heart of Kenya.htm. Accessed 1 January 2020.

Azadi, H \& Vanhaute, E, 2019. Mutual Effects of Land Distribution and Economic Development: Evidence from Asia,Africa, and Latin America. Land 8 (96). www.mdpi.com/journal/land. Accessed 2 February 2020.

Basset, TJ \& Gautier, D, 2014 (2014). Regulation by Territorialization: The Political Ecology of Conservation and Development Territoris. EcoGeo. http://journals.openedition.org/echogeo/14038 ; DOI : 10.4000/echogeo.14038. Accessed 7 February 2020.

Bedelian, C. 2014. Conservation, tourism and pastoral livelihoods: Wildlife conservancies in the Maasai Mara, Kenya. PhD Thesis. University College, London.

Bedelian, C \& Ogutu, JO, 2017. Trade-offs for climate-resilient pastoral livelihoods in wildlife conservancies in the Mara ecosystem, Kenya. Pastoralism 7 (10).

Blench, R, 2001. You can't go home again. Pastoralism in the new millennium. Overseas Development Institute, London.

Bourn, D \& Blench, R (eds), 1999. Can livestock and wildlife co-exist?: An interdisciplinary approach. Overseas Development Institute Oxford, UK.

Brockington, D, 2003. Injustice and conservation-is 'local' support necessary for susainable protected areas? Policy Maters 12, 22-30.

Burrow, E \& Murphree, M, 2001. community conservation: from concept to practices. In Hulme, D \& Murphree, M, (eds). African Wildlife and livelihoods: the promise and performance of community conservation. James Currey Ltd, UK.

Byakagaba, P, Egeru, A, Barasa, B \& Briske, DD, 2018. Uganda's rangeland policy: intentions, consequences and opportunities. Pastoralism 8(7). 
Chatty, D, 2003. Mobile peoples and conservation: An introduction. Nomadic Peoples 7 (1), 516.

Chatty, D, 2012. Workshop report: Dana Declaration +10. Refugee Studies Centre, Oxford Department of International Development, Oxford.http://www.danadeclaration.org/ dana10/dana-participant-statement-en.pdf. Accessed 22 September 2019.

Chatty, D \& Colchester, M, 2002. Introduction: conservation and mobile indigenous peoples. In Chatty, D \& Colchester, M (Eds.) Conservation and mobile indigenous peoples. Berghahn Books, Oxford.

Conservation Capital, 2019. Building a Wildlife Economy. Developing Nature-Based Tourism in African State Protected Areas. Space for Giants. https://www.researchgate.net/ publication/336028655.

Dana Declaration, 2002. Dana Declaration on Mobile Peoples and Conservation. http://www.danadeclaration.org. Accessed 22 September 2019.

Eagles, PFJ, McCool, S F \& Haynes, C DA, 2002. Sustainable Tourism in Protected Areas. Guidelines for Planning and Management. In Phillips, A ( ed). Best Practice Protected Area Guidelines Series No. 8. IUCN. Gland, Switzerland and Cambridge, UK.

Egeru, A, Wasonga,O Kyagulanyi, J, Majaliwa, GJM, MacOpiyo, L, \& Mburu, J, 2014. Spatiotemporal dynamics of forage and land cover changes in Karamoja sub-region, Uganda. Pastoralism 4 (1), 6.

Elliott, SM \& Mann, S, 2005. Development, Poverty and Tourism: Perspectives and Influences in Sub-Saharan Africa. Occasional Paper Series. The George Washington Centre for the Study of Globalization (GWCSG). Washington D.C, US.

Enne, C, 2003. Understanding the Economic impact of tourism. Som Nath Chib Memorial Lecture. 14 Feb , Nottingham. http://citeseerx.ist.psu.edu/viewdoc/download? doi=10.1.1.567.8713\&rep=rep1\&type=pdf. Accessed 22 September 2019.

Environment Liaison Centre International (ELCI), 2006. Pastoralism as a Conservation Strategy and Contribution in Livelihood Security. https://www.iucn.org/sites/dev/files/import /downloads/kenya_country_study.pdf. Accessed 7 February 2020.

FAO (n.d). Rural households and the environment. http://www.fao.org/3/V5406e /v5406e02. htm. Accessed 2 February 2020.

Galaty, J, 2013. Land grabbing in the Eastern African rangelands. In Catley, A, Lind, J \& Scoones, I (Eds), Pastoralism and development in Africa: Dynamic change at the margins, Routledge, London. 
Gitau, JW (ed.), 2014. Payment for wildlife conservation in the Maasai Mara ecosystem. ABCD Series Policy Brief 2. Entebbe, Uganda: Association for the Strengthening of Agricultural Research in Eastern and Central Africa. http://cmsdata.iucn.org/downloads/policy_brief_ payment_for_wildlife_conservation_in_the_maasai_mara_ecosystem.pdf. Accessed 22 September 2019.

Goodwin, H, 1998. Sustainable tourism and poverty alleviation. A background paper for DFID/DETR workshop on Sustainable tourism and poverty (Unpublished).

Goodwin, H, 2002. Local Community Involvement in Tourism around National Parks: Opportunities and Constraints. Current Issues in Tourism. 5 (3\&4), 338-360.

Green,DS, Zipkin, EF, Incorvaia, DC, Holekamp, KE, 2019. Long-term ecological changes influence herbivore diversity and abundance inside a protected area in the Mara-Serengeti ecosystem. Global Ecology and Conservation 20.

Hackel, JD, 1999. Community conservation and the future of Africa's wildlife. Conservation Biology 13(4),726-734.

Hesse, C, \& MacGregor, J, 2006. Pastoralism: drylands' invisible asset? Developing a framework for assessing the value of pastoralism in East Africa. iied Issue paper no. 142.

Homewood, KM, Trench, PC \& Brockington, D, 2012. Pastoralist livelihoods and wildlife revenues in East Africa: a case for coexistence? Pastoralism: Research, Policy and Practice, 2 (19).

Humanitarian Policy group, 2009. Pastoralism, policies and practice in the Horn and East Africa A review of current trends. ODI-UK.

Ioannides, D, 2003. The Economics of Tourism in Host communities. In Singh, S, Timothy, DJ \& Dowling, R K. Tourism in Destination communities. CABI Publishing, UK.

Ipara, H, 2013. The tenure factor in wildlife conservation: The case of Kakamega forest national reserve. In Akama, JS (Ed). Tourism Development in Kenya: Critical issues, challenges and alternatives in the new millennium. East African Educational Publishers Ltd., Nairobi.

IWGIA, Sørensen, C \&Vinding, D (eds), 2016. Tanzanian Pastoralists threatened. Eviction, Human rights violation and loss of livelihoods. IWGIA report 23. IWGIA. Denmark. https://www.iwgia.org/images/publications//0727_Report_23_Tanzania_for_eb.pdf. Accessed 25 September 2019.

Jenet, AN. Buono, S. Di Lello, M. Gomarasca, C. Heine, S. Mason, M. Nori, R. Saavedra, K. Van Troos, 2016. The path to greener pastures. Pastoralism, the backbone of the world's drylands. Vétérinaires Sans Frontières International (VSF-International). Brussels, Belgium. 
Kamsma, T \& Bras, K, 2000. Gili Trawangan-From desert island to 'marginal' paradise. Local participation, small-scale entrepreneurs and outside investors in an Indonesian tourist destination. In Richard, G \& Hall, D (eds). Tourism and sustainable community development. Routledge, London.

Kaye-Zwiebel, E, \& King, E, 2014. Kenyan pastoralist societies in transition: varying perceptions of the value of ecosystem services. Ecology and Society 19 (3), 17. http://dx.doi.org/10.5751/ES-06753-190317. Accessed 2 February 2020.

Kenya National Bureau of Statistics, 2001. Economic Survey. Government printers, Nairobi.

Kenya Government, 2004. Draft National Tourism Policy. Government Press, Nairobi.

Kenya Government, 2007. Economic Survey. Government Press, Nairobi.

Kenya Government, 2012a. Economic Survey. Government Press, Nairobi.

Kenya Government, 2012b. National Policy for the Sustainable Development of Northern Kenya and other Arid Lands. Releasing Our full Potential. Sessional Paper No. 8 of 2012. Kenya government printers, Nairobi.

Kenya Government, 2017a. Land use policy. Sessional Paper No. 1. Kenya government printers, Nairobi.

Kenya Government, 2017b. Draft National Policy for the sustainable development of ASALs. Kenya government printers, Nairobi.

Kenya National Bureau of Statistics (KNBS), 2018. Economic Survey. Government printers, Nairobi.

Kenya Land Alliance, 2016. Land use in Kenya. The Case for national land use policy. Land reform vol. 3. Kenya Land Alliance, Nairobi.

Kenya Wildlife Conservancies Association, 2016. State of Wildlife Conservancies in Kenya Report. https://kwcakenya.com/wp-content/uploads/2018/01/SoC-Report.pdf. Accessed 25 September 2019.

Kideghesho, JR, 1999. Conflict management in protected areas in Kakakuona: Tanzania Wildlife Magazine, No. 12, February to April.

Kieti, DM \& Akama, JS, 2005. Wildlife safari tourism and sustainable local community development in Kenya. Journal of Hospitality \& Tourism.3 (2), 71-81.

Kieti, D, 2007. The Efficacy of Tourism Development Models in Poverty Reduction. PhD Thesis. Moi University, Kenya. 
Kieti, D, Jones, E \& Wishitemi, B, 2009. Alternative models of community tourism: Balancing economic development and the aspirations of the poor. Tourism Review International (Special Issue), 12.

Kiss, A, 2004. Is community-based ecotourism a good use of biodiversity conservation funds? Trends in Ecology and Evolution 19, 232-237.

Knoema, 2019. Contribution of travel and tourism to GDP as a share of GDP. https://knoema.com. Accessed 2 February 2020.

Kristjanson, P, Radeny, M. Nkediange, D. Kruska, R. Reid, R. Gichohi, H. Atieno, F \& Stanford, $\mathrm{R}, 2002$. Valuing alternative land-use options in the Kitengela Wildlife dispersal areas of Kenya. ILRI Impact Assessment Series 10. International Livestock Research Institute, Nairobi.

Massé, F, 2016. The political ecology of human-wildlife conflict: Producing wilderness, insecurity, and displacement in the Limpopo National Park. Conservat Soc 14:100-11. http://www.conservationandsociety.org/text.asp?2016/14/2/100/186331. Accessed 7 February 2020.

McLean, J \& Straed, S, 2003. Conservation, Relocation, and the Paradigms of Park and People Management--A Case Study of Padampur Villages and the Royal Chitwan National Park, Nepal, Society \& Natural Resources, 16:6, 509-526, DOI: 10.1080/08941920309146.

Metcalf, S, 1994. Zimbabwe communal areas management programme for indigenous resources (CAMPFIRE) in Right, RM \& Western, B, (Eds),. Natural Connections: Perspectives on community based conservation. Island Press, Washington D.C.

inistry of Tourism, 2010. Domestic Tourism Strategy Taskforce Report-2010. Nairobi http://www.tourism.go.ke/ministry.nsf/pages/news 18jan10. Accessed March 6, 2019.

Ministry of Tourism \& Wildlife, 2018a. National Wildlife Strategy 2030. Abridge Version. Blueprint to transform wildlife conservation in Kenya. Nairobi, Kenya.

Ministry of Tourism \& Wildlife, 2018b. Tourism Sector Performance report-2018. Nairobi. http://ktb.go.ke/wp-content/uploads/2019/01/Tourism-Performance-2018-PresentationFinal2.pdf. Accessed 5 June 2019.

Mureithi, SM. Verdoodt, A. Njoka, JT. Olesarioyo, JS. Van Ranst, E, 2019. Community based conservation: An emerging land use at the livestock-wildlife interface in Northern Kenya. DOI: 10.5772/intechopen.73854. Access 26 September 2019.

Musavengane, R. \& Simatele, DM, 2016. Community-based natural resource management: The role of social capital in collaborative environmental management of tribal resources in KwaZulu- 
Natal, South Africa. Development Southern Africa 33 (6), 806-821.

https://doi.org/10.1080/0376835X. 2016.1231054. Accessed 2 February 2020.

Nelson, F (eds), 2010. Community Rights, Conservation and Contested Land. The Politics of Natural Resource Governance in Africa. Earth Scan. London.

Nelson, F, 2012. Natural Conservationists? Evaluating the impact of pastoralists land use practice in Tanzanian's Wildlife Economy. Pastoralists: Research, Policy and Practice, 2 (15).

Notenbaert, AMO, Davis, J, De Leeuw, J, Said, M, Herrero, M, Manzano, P, Waithaka, M, Aboud, A \& Omondi, S, (2012). Policies in support of pastoralism and biodiversity in the heterogeneous drylands of East Africa. Pastoralism: Research, Policy and Practice, 2 (14).

Nunkoo, R, 2015. Special issue: Tourism and hospitality development in African economies: Perspectives and challenges, Development Southern Africa, 32:3, 275-276. http://dx.doi.org/10.1080/0376835X.2015.1021035. Accessed 2 February 2020.

Obunde, PO, Omiti, JM \& Sirengo, AN, 2005. Policy Dimensions in Human-Wildlife Conflicts in Kenya: Evidence from Laikipia and Nyandarua Districts. Policy Brief. 11 (3), 1-4.

Odote, C, 2013. The dawn of Uhuru? Implications of constitutional recognition of communal land rights in pastoral areas of Kenya. Nomadic Peoples. 17(1), 87-105.

Ogutu, JO, Piepho, HP, Said, MY, Ojwang, GO, Njino, LW, Kifugo, SC \& Wargute, PW, 2016. Extreme Wildlife Declines and Concurrent Increase in Livestock Numbers in Kenya: What Are the Causes? PLoS ONE 11 (9): e0163249. doi:10.1371/journal.pone.0163249. Accessed 7 February 2020.

Ogutu, JO, Kuloba B, Piepho, HP, Kanga, E, 2017. Wildlife Population Dynamics in HumanDominated Landscapes under Community-Based Conservation: The Example of Nakuru Wildlife Conservancy, Kenya. PLoS ONE 12(1): e0169730. https://doi.org/10.1371/journal.pone.0169730. Accessed 7 February 2020.

Okello, MM, 2005. A Survey of Tourist Expectations and Economic Potential for a Proposed Wildlife Sanctuary in a Maasai Group Ranch near Amboseli, Kenya. Journal of Sustainable Tourism. 13 (6), 566-589.

Okello, MM \& Wishitemi, BEL, 2013. Wildlife dispersal areas and migration corridors: Role of the Maasai. In Akama, J S (Ed). Tourism development in Kenya: Critical issues, challenges and alternatives in the new millennium. East African Educational Publishers Ltd., Nairobi.

Pas Schrijver, A, 2019. Pastoralists, Mobility and Conservation. Shifting rules of access and control of grazing resources in Kenya's northern drylands. PhD Thesis. Department of Human 
Ecology. Stockholm University. http://urn.kb.se/resolve?urn=urn:nbn:se:su:diva-162137. Accessed 7 February 2020.

Quan, J, Tan, SF \& Toulm, C, (eds) 2014. Market asset or secure livelihood? Proceedings and summary of conclusions from the Land in Africa Conference held in November 8-9, London, UK.

Reid, JN, 2002. Poverty, race and community in rural places. The empowerment approach. Paper prepared for presentation at the International Community Development Society Conference, 23 July, Cleveland, Mississippi.

Riggio, J, Jacobson, AP, Hijmans, RJ \& Caro, T, 2019. How effective are the protected areas of East Africa? Global Ecology and Conservation 17. e00573. Accessed on 2 February 2020.

Segovia Declaration, 2007. Segovia declaration of nomadic and transhumant pastoralists. 14 September,La Granja, Segovia . www.danadeclaration.org/pdf/SegoviaDeclaration.pdf. Accessed 22 September 2019.

Signe', L, 2018. Africa's Tourism Potential: Trends, Drivers, Opportunities and Strategies. Africa Growth Initiative. www. brookings. edu/global. Accessed 5 June, 2019.

Sindiga, I, 1999. Tourism and African Development: Change and Challenge of Tourism in Kenya. Ashgate Publishing Limited, Leiden.

Spenceley, A \& Goodwin, H, 2007. Nature-based tourism and poverty alleviation: Impacts of private sector and parastatal enterprises in and around Kruger National Park, South Africa. Current Issues in Tourism. 10 (2), 255-277.

Stark, J, 2013. Climate Change and Conflict in Africa And Latin America: Findings and Preliminary Lessons from Uganda, Ethiopia and Peru. Tetra Tech ARD, USA.

Thompson, M, \& Homewood, K, 2002. Elites, entrepreneurs and exclusionin Maasailand. Human Ecology30 (1), 107-138.

Timothy, DJ \& Tosun, C, 2003. Appropriate planning for tourism in destination communities: participation, incremental growth and collaboration. In Singh, S, Timothy, DJ \& Dowling, RK (Eds). Tourism in destination communities. CABI Publishing, UK.

Tosun, C, 1998. Roots of Unsustainable tourism development at the local level: the case of Urgup in Turkey. Tourism Management 19 (6), 595-610. 
Tumusiime, DM \& Vedeld, P, 2012. False Promise or False Premise? Using Tourism Revenue Sharing to Promote Conservation and Poverty Reduction in Uganda. Conservation and Society 10(1): 15-28.

Tumusiime, D, Nalule, AS \& Nalubwama, S, 2018. Paradigm shifts in rangeland communities' livelihoods activities as coping strategies to climate variability and restricted mobility. Livestock Research for Rural Development 30 (6). http://www.lrrd.org/ lrrd30/6/snalu30100.html. Accessed 2 February 2020.

United Nations, 2008. Achieving Sustainable Development and Promoting Development Cooperation. United Nations Publications. New York. https://www.un.org/en/ecosoc/docs/pdfs/fina_08-45773.pdf. Accessed 15 September 2019.

UNWTO, 2017. UNWTO Annual Report 2015. UNWTO, Madrid.

UNWTO, 2018. UNWTO Tourism Highlights 2018 Edition. Madrid. https://www.eunwto.org/doi/pdf/10.18111/9789284419876. Accessed 5 June 2019.

UNWTO, 2019. World Tourism Barometer, January, 2019. https://www.ttr.tiro. Accessed 5 June 2019.

Upton, C, 2014. The new politics of pastoralism: Identity, justice and global activism. Geoforum. 54, 207-216.

Vaccaro, I, Beltran, O \& Paquet, PA, 2013. Political Ecology of Conservation: some theoretical genealogies. Journal of Political Ecology 20. DOI: 10.2458/v20i1.21748. Accessed 7 February 2020.

Wall, G \& Long, V, 1996. Balinese homestays: an indigenous response to tourism opportunities. In Butler, R \& Hinch, T (Eds), Tourism and indigenous peoples. International Tourism Business Press, UK.

Wearing, SL \& McDonald, M, 2002. The development of community based tourism: Rethinking the relationship between intermediaries and rural and isolated area communities. Journal of Sustainable Tourism. 10 (2), 31-45.

Wishitemi, BEL \& Okello, MM, 2003. Application of the Protected Landscape Model in southern Kenya. Parks. 13 (2), 12-21.

World Alliance of Mobile Indigenous Peoples (WAMIP), 2004. Briefing notes on mobile peoples and conservation. http://data.iucn.org/themes/ceesp/WAMIP/WAMIP\%20Briefing\%20 Notes\%20Fall\%202004.pdf, Accessed 22 September 2019. 
World Bank 2013. Land in Africa. Land Policies for Growth and Poverty reduction. Oxford University Press. Washington.

World Bank (2014): Tourism in Africa: Harnessing Tourism for Growth and Improved Livelihoods. https://www.worldbank.org/content/dam/Worldbank/document/Africa/Report/ africa-tourism-report. Accessed 2 February 2020.

World Initiative for Sustainable Pastoralism (WISP), 2008. Forgotten services, diminished goods: Understanding the agroecosystem of pastoralism. Policy note No. 8.

https://www.iucn.org/sites/dev/files/import/downloads/forgotten_services_diminshed_goods_u nderstanding_the_agroecosysem_of_pastoralism.pdf Accessed 22 September 2019.

World Initiative for Sustainable Pastoralism (WISP). 2013. Global Gathering of pastoralists, Kiserian, Kenya, December. http://www.iucn.org/wisp/ Accessed 22 September 2019.

Yurco, K, 2017. Herders and herdsmen: The remaking of pastoral livelihoods in Laikipia, Kenya. Pastoralism 7, 15. https://doi.org/10.1186/s13570-017-0086-0. Accessed 7 February 2020. 